\title{
FACTORS RELATED TO OPEN DEFECATION BEHAVIOR AMONG SCHOOL- AGE CHILDREN IN WEST LOMBOK
}

\author{
Makhfudli, Praba Diyan Rachmawati, Saskiyanti Ari Andini \\ Faculty of Nursing, Universitas Airlangga, Kampus C Mulyorejo Surabaya, 60115 \\ Email: saskiyaandini@gmail.com
}

\begin{abstract}
Introduction: Open defecation behavior is one cause of poor sanitation, which can lead to various diseases. Open defecation behavior related with cultural factors that become a habit in the daily life in a society which was then followed by their children. This study aimed to analyze factors related to the parental behavior of open defecation in school-age children based on the theory of transcultural nursing in Marce, Sedau Community Health Center Area, West Lombok Indonesia. Methods: This was a descriptive research design with cross-sectional approach. Samples were taken by simple random sampling technique and obtained 95 parents of children aged 7-12 years. Independent variables were education level, economy level, cultural values and lifestyle, social and family values, religiosity, technology. The dependent variable was open defecation behavior of the parents in school age children. This research was analyzed using Spearman rho test with significance level $\alpha$ $=0.05$. Results: education level $(\mathrm{p}=0.000 ; \mathrm{r}=0.390)$, economy level $(\mathrm{p}=0.003 ; \mathrm{r}=0.298)$, cultural values and lifestyle $(\mathrm{p}$ $=0.000 ; \mathrm{r}=0.555)$, social and family $(\mathrm{p}=0.000 ; \mathrm{r}=0.444)$, religiosity $(\mathrm{p}=0.000 ; \mathrm{r}=0.300)$, technology $(\mathrm{p}=0.000 ; \mathrm{r}=$ 0354) has a significant relationship with the parents about the open defecation behavior in school age children. Conclusion: the intervention was needed on the factors that influence the open defecation behavior by nurses participating directly to communities to increase public awareness about the importance of healthy defecate in a closet to avoid the disease.
\end{abstract}

Keywords: parent's behavior, open defecation, school-age children, transcultural nursing theory

\section{INTRODUCTION}

The behavior of Open Defecation is one cause of poor sanitation. It can cause various diseases, and it is an example of unhealthy behaviors (Mukherjee 2011). Open defecation behavior is closely connected with a cultural factor which is a habit in daily life (Qudsiyah WA; Pujiati, RS; Ningrum 2015). Initial data retrieval conducted by the researcher showed a lot of people who do open defecation behavior has become a habit for the majority of people. They usually do defecation in the river, so their children follow this habit. Children are more likely to imitate the same model which can be reached by them, seeing other children or people around them (Latifah 2012).

Based on the United Nations International Children's Emergency Fund (UNICEF) data in 2015, Indonesia is the second country with open defecation behavior in the world. According to the Join Monitoring Program (JMP) of WHO / UNICEF 2015, approximately 51 million Indonesian have still been doing open defecation behavior. Based Health Research in 2013 (RISKESDAS) West Nusa Tenggara is the second province that has the largest number defecation in Indonesia. (Dinas Kesehatan Kabupaten Lombok Barat 2012), there was $52.48 \%$ of people have already used family latrines as places to defecate (BAB), 27.21\% still used the river and the surrounding environment as a place to defecate. Open defecation behavior affects sanitation issues such as diarrhea, as shown by the data of the West Lombok Department of Health 2014, the incidence of diarrhea at Puskesmas Sedau West Lombok was extremely high with 1036 inhabitants.

The interview data conducted by Ahmad Hazrul Watoni on 29 September 2016 in children aged 7-12 years who live in Merca, Selat Village, where it was on of Puskesmas Sedau area, showed that there were 11 out of 20 people have defecation habit in the river even though 7 out of 11 children had latrines in their house, while the remaining has already used toilet. Those 11 people were from parents whose education in junior high school. According to research results, (Qudsiyah WA; Pujiati, RS; Ningrum 2015) explain that quality of latrine does not affect a person to defecate in latrines, this is caused by their habit that they are more comfortable to defecate in the river. Infrastructure is an enforcing factor for behavioral change, but the most dominating factor is the habit.

Theory of Transcultural Nursing with Sunrise model of (Leininger 2002) consists of 
seven factors influencing the belief and practice of the individual or cultural group. It affects specific and universal nursing practice to health and welfare of the individual or cultural group (Leininger 2002) so that it can be used as a template to observe the factors relating to the behavior of open defecation. Various problems from these conditions will relate to the behavior of open defecation in children.Therefore researcher is interested in doing research on "Analysis of Factors Related to Open Defecation Behavior based on Theory of Transcultural Nursing at Children in Merca, Selat Village, West Lombok".

\section{METHOD}

This research design uses descriptive with cross sectional approach. The population in the study were all parents with school-aged children (7-12 years) in Merce, Selat village, Sedau Community Health Center area. In this study, the researcher used simple random sampling technique and obtained a sample of 95 respondents. Independent variables in this research are parent education, cultural values and lifestyle, social and family value, religiosity, and technology, while the dependent variable is open defecation behavior in school age children.

Data collection using questionnaire and implemented for three weeks in December 2016. Analysis of data used to determine the relationship factors associated with open defecation behavior is to use Spearman rho test.

\section{RESULTS}

Over half of respondents graduated from secondary education. It means education pursued by respondents were still lacking. Education has a significant relationship with open defecation behavior in children (Table $1)$.

Based on Table 2, the majority of respondents had a low economy status which was below the minimum wage of Lombok Barat $(<1,500,000)$, these results indicate a significant relationship between economic status and open defecation behavior of schoolaged children.

Table 1. The relationship between parent's education and parent's behavior about open defecation to school age children

\begin{tabular}{|c|c|c|c|c|c|c|c|c|c|c|c|}
\hline \multirow{3}{*}{$\begin{array}{l}\text { Open Defecation } \\
\text { Behavior }\end{array}$} & \multicolumn{11}{|c|}{ Education } \\
\hline & \multicolumn{2}{|c|}{$\begin{array}{l}\text { Did not attend } \\
\text { school }\end{array}$} & \multicolumn{2}{|c|}{$\begin{array}{l}\text { Elementary } \\
\text { school }\end{array}$} & \multicolumn{2}{|c|}{$\begin{array}{l}\text { Junior high } \\
\text { school }\end{array}$} & \multicolumn{2}{|c|}{$\begin{array}{l}\text { Senior High } \\
\text { School }\end{array}$} & College & \multicolumn{2}{|c|}{ Total } \\
\hline & $\sum$ & $\%$ & $\bar{\sum}$ & $\%$ & $\sum$ & $\%$ & $\sum$ & $\%$ & $\sum \%$ & $\bar{\sum}$ & $\%$ \\
\hline Do not do & 0 & 0 & 1 & 1.1 & 19 & 20 & 18 & 18.9 & $\begin{array}{ll}6 & 6.3\end{array}$ & 44 & 46. \\
\hline Do & 4 & 4.2 & 10 & 10.5 & 31 & 32.6 & 5 & 5.3 & 11.1 & 51 & 53. \\
\hline Total & 4 & 4.2 & 11 & 11.6 & 50 & 52.6 & 23 & 24.2 & $\begin{array}{ll}7 & 7.4 \\
\end{array}$ & 95 & 100 \\
\hline
\end{tabular}

Table 2. The relationship between economic background and open defecation behavior in school age children

\begin{tabular}{|c|c|c|c|c|c|c|}
\hline \multicolumn{7}{|c|}{ Economic } \\
\hline \multirow{2}{*}{$\begin{array}{l}\text { Behavior Open } \\
\text { Defecation }\end{array}$} & \multicolumn{2}{|c|}{$\leq 1500000$} & \multicolumn{2}{|c|}{$\geq 1500000$} & \multicolumn{2}{|c|}{ Total } \\
\hline & $\Sigma$ & $\%$ & $\Sigma$ & $\%$ & $\Sigma$ & $\%$ \\
\hline Do not do & 22 & 23.2 & 22 & 23.2 & 44 & 46.3 \\
\hline Do & 40 & 42.1 & 11 & 11.5 & 51 & 53.7 \\
\hline Total & 62 & 65.3 & 33 & 34.7 & 95 & 100 \\
\hline & & $\mathrm{p}=0$. & 0.29 & & & \\
\hline
\end{tabular}


Factors Related to Open Defecation Behavior (Makhfudli et.al.)

Table 3. The relationship between cultural value and lifestyle and open defecation behavior in school age children

\begin{tabular}{|c|c|c|c|c|c|c|}
\hline \multicolumn{7}{|c|}{ Cultural Value and Lifestyle } \\
\hline \multirow[t]{2}{*}{ Open Defecation Behavior } & \multicolumn{2}{|c|}{ Negative } & \multicolumn{2}{|c|}{ Positive } & \multicolumn{2}{|l|}{ Total } \\
\hline & $\Sigma$ & $\%$ & $\Sigma$ & $\%$ & $\Sigma$ & $\%$ \\
\hline Do not do & 11 & 11.5 & 33 & 34.8 & 44 & 46.3 \\
\hline Do & 41 & 43.2 & 10 & 10.5 & 51 & 53.7 \\
\hline Total & 52 & 54.7 & 43 & 45.3 & 95 & 100 \\
\hline \multicolumn{7}{|c|}{$\mathrm{p}=0.00, \mathrm{r}=0.555$} \\
\hline
\end{tabular}

Table 4. The relationship between social and family value with open defecation behavior in school age children

\begin{tabular}{lcccccccc}
\hline & \multicolumn{9}{c}{ Social and Family Value } \\
\hline Open Defecation Behavior & Negative & \multicolumn{3}{c}{ Positive } & & Total & \\
& $\Sigma$ & $\%$ & $\Sigma$ & $\%$ & 5 & $\%$ \\
\hline Do not do & 9 & 9.5 & 35 & 36.8 & 44 & 46.3 \\
\hline Do & 33 & 34.7 & 18 & 19 & 51 & 53.7 \\
\hline Total & 42 & 44.2 & 53 & 55.8 & 95 & 100 \\
\hline \multicolumn{7}{c}{$\mathrm{p}=0.00, \mathrm{r}=0.444$} \\
\hline
\end{tabular}

Table 5. Distribution of respondents by cultural value and lifestyle of parents associated with open defecation behavior in school age children

\begin{tabular}{lcccccccc}
\hline \multirow{2}{*}{ Open Defecation Behavior } & \multicolumn{9}{c}{ Religiosity } & \multicolumn{1}{c}{ Less } & \multicolumn{2}{c}{ Total } \\
\cline { 2 - 10 } & \multicolumn{2}{c}{ Good } & $\%$ & $\sum$ & $\%$ & $\sum \%$ & $\sum$ & $\%$ \\
\cline { 2 - 10 } Do not do & 44 & 46.3 & 0 & 0 & 0 & 0 & 44 & 46.3 \\
\hline Do & 51 & 53.7 & 0 & 0 & 0 & 0 & 51 & 53.7 \\
\hline Total & 95 & 100 & 0 & 0 & 0 & 0 & 95 & 100 \\
\hline & \multicolumn{8}{c}{$\mathrm{p}=0.000, \mathrm{r}=0.300$} \\
\hline
\end{tabular}

Table 6 The Relationship between Technological factors and Open Defecation Behavior of school age children

\begin{tabular}{|c|c|c|c|c|c|c|c|}
\hline \multirow{3}{*}{ Open Defecation Behavior } & \multicolumn{4}{|c|}{ Technology } & & & \\
\hline & \multicolumn{2}{|c|}{ Good } & \multicolumn{2}{|c|}{ Moderate } & \multirow{2}{*}{$\begin{array}{c}\text { Less } \\
\sum \%\end{array}$} & \multicolumn{2}{|c|}{ Total } \\
\hline & $\sum$ & $\%$ & $\sum$ & $\%$ & & $\sum$ & $\%$ \\
\hline Do not do & 34 & 35.8 & 8 & 8.5 & 22.1 & 44 & 46.3 \\
\hline Do & 23 & 24.2 & 14 & 14.7 & 14.7 & 51 & 53.7 \\
\hline Total & 57 & 60 & 22 & 23.2 & 1616.8 & 95 & 100 \\
\hline & & & & $r=0$ & & & \\
\hline
\end{tabular}

According to the table 3, more than half of the respondents had negative cultural value and lifestyle. The relationship level between cultural value and lifestyle and open defecation behavior high was. This shows that the habit of open defecation was still very high.
The relationship level between social and cultural value and parent's behavior was moderate (Table 4), this indicates that the value of social and family supported hygienic and healthy behavior, especially Open Defecation was still very good. 
According to Table 5, the majority of respondents had a good value to religiosity and level of religiosity with the behavior of open defecation was moderate. This shows that the people believe in their religion teach to maintain good hygiene.

The majority of respondents had a good Technology. The relationship level of technology with the behavior of open defecation was moderate (Table 6). This shows that the technology available has been good to support the behavior of the positive open defecation.

\section{DISCUSSION}

Based on the data showed that the majority education of respondents was junior high school. This indicates that respondents were less educated. Therefore, there is correlation proved by the test Spearman Rho between education and the parental behavior of open defecation.

Education is an important thing, high education is expected to make a person always to carry out the things that are important to themselves and those around them (Mahyudin, 2013). According to the theory of Leininger's Transcultural Nursing (2002) states that a healthy behavior is shaped by a variety factors that work together. The higher education, the wiser that person is understanding everything around them because they usually look for scientific evidence and rational mind. It makes easier to adapt culturally as well as their health condition. Formal education of mother is the impact of mother's knowledge which low education leads to be less education and vice versa. Knowledge is an important domain for the person's actions (Kharismawati 2014).

Respondents who studied high school and college also had the negative open defecation is caused by lack of knowledge and information in the use of a healthy toilet.The society's knowledge was high but still behave open defecation although already have their own latrines as defecating. It indicates that public's knowledge about healthy latrine is still lacking (Widowati 2015) and the participation of the family in the use of latrines is still lacking (Tarin, 2008). Also, well-educated parents usually have many activities outside, so they will leave their children (Syaltut 2016)(Syaltut 2016) so that the children is handed over to grandmother or neighbor. Thus, children are rarely given the knowledge of the proper place and manner of defecation to keep hygiene.

Education is an important factor for people to behave maintaining the health of family, but it will be useless if it is not accompanied by awareness and willingness to make changes and improvements in the family environment, as well as respondents with high education, such as graduated from high school and college,they do not build their own latrines for house because their house is close to the river without a septic tank.

The most respondents were less economic, which was under minimum wage of West Lombok $(<1,500,000)$. Respondents who earned below minimum wage had negative open defecation behavior, so the Spearman rho indicates the relationship between the economic and parental behavior of open defecation children. The level of the relationship was a moderate level category. Family income determines the availability of good family health. A balance family income will affect in maintaining the cleanliness and provision of a health facility. So people with low income cannot afford good health facility because they are difficult in providing it (Ministry Of Health, 2006). Theory of Transcultural Nursing (Leininger 2002) explains that someone will take advantage of material resources owned to pay its pain to get well soon.

Widowati (2015) found that income is a factor associated with health program, which means people with sufficient income will defecate in latrines while others with low income mostly do open defecation in greater number than high income. Statistically, there is a significant relationship between income and open defecation behavior. A respondent with low income was likely to have 9500 times risk more than respondents with high income.

However, there were respondents with a good economy doing open defecation behavior.This is caused by several factors encouraging them to do open defecation, which was people living near the river were more at risk to defecate in the open area (Mukherjee 2011). Another study mentioned that the distance between home and the river affects 132 times not to build latrine (Salah, 2002). Another factor that could reduce the 
influence of technology is culture open defecation in the community because they felt defecation be more convenient and practical, open defecation as community identity and inheritance - generation of the ancestor so that it becomes a habit (Murwati 2012).

Low economy status strongly supports the behavior of open defecation because people will set a priority on another need which is more fundamental than building their own latrines especially if the distance from the house to the river near. Moreover, limited of land-owner makes difficult to build latrines so awareness for has a healthy family latrine will be less.

Most respondents had the negative value of cultural and lifestyle, among them, there were people with negative behavior of open defecation. There was a significant relationship between the test Spearman Rho between cultural value and lifestyle and the parental behavior of open defecation children. The level of a relationship was high. Based on research (Qudsiyah WA; Pujiati, RS; Ningrum 2015), the behavior of open defecation is closely connected with the cultural factor that becomes a habit in daily life, they feel more comfortable if defecate in the river while facility and infrastructure are enforcing factor to change behavior, but the most dominating factor is the habit.

The tribe characteristics can be described by the tradition and culture which is formed in settlement and their local wisdom. It can be seen from the traditional settlement of Sasak Tribe, in Limbungan, East Lombok, who maintain their traditional house from any changes. The pattern of spatial development of the Sasak tribe in Limbungan is based on cosmology value-oriented with the belief system and tradition of culture-based society resulting in special space. Custom regulations about the settlement of indigenous Limbungan that if you want to build a permanent house, you should build outside the area neighborhood of custom, it is forbidden to alter and damage the residential custom, location, natural materials of the building, all of this should be in accordance with the custom rules, especially it is not allowed to build bathroom/toilet in custom residential neighborhood that washing activities carried out in the river (Sabrina, R., Antariksa, A., \& Prayitno 2010).
Attitude and behavior of people who does not maintain environmental health have an impact on their next-generation behavioral patterns. Cultural elements learned in the early stages of the process of socialization are a habit formed since childhood. It will affect the habit of a person as an adult (Koentjaraningrat 2004).

Community with high cultural value will follow their tradition of the past and feel comfortable when they are in situation and condition where the present and the future can be predicted or have a secure while community with low cultural value will remain comfortable even if they are in a situation that is uncertain in the present and future, therefore they are not too oriented to regulation and better prepared to face the changes (Imelda 2002).

Based on Transcultural nursing theory Leininger (2002), the value of culture is defined and determined by the adherents of culture considered as good or bad. One of the factors that determine the health condition of the community is the people's health behavior itself, where several factors influence the process of formation of this behavior. Its factor socio-cultural factor, if these factor has been embedded and internalized in the life and activity of the community the tendency to change behavior been formed is difficult to do (Imelda 2002).

The value of the negative culture associated with a parental behavior of open defecation would be inherited by their children and will continue to inherit if the parents do not change a value of culture to be positive because children will imitate whatever is done by family environment.A custom which has been learned from childhood by family is a difficult thing to be changed because people prefer their lives as usual and trying to keep things comfortable so that the relationship between culture and parental behavior of open defecation to children were high.

Most respondents have good social value and family. It indicates there was the relationship between social value and family and parental behavior of open defecation to children. The level of the relationship was moderate.

Transcultural nursing by Leininger (2002), Social \&family aims to be a support system for member and to improve health and 
the adaptation process. Social and family supports the family's ability to provide time, attention, and support to meet the physical, mental, and social. There are three dimensions of family support such as emotional support, material support, informative support. Social and family factor have an important role in the medical management not only for children but also for the adult who can affect behavior.

There were 18 people who have positive social value and family doing open defecation. Low parental supervision can cause this behavior. Low family care causes parents had a negative characteristic in determining the way to care children (Syaltut 2016).

Parental care of children affects the care for children and forms of a family also affects parental attention to children. According to Feiring and Lewis (1984) in Friedman (2010), there is strong evidence that large family and small family qualitatively describe the experiences of development. Children who come from small family receive more attention than children from large family so that it becomes a factor supporting the behavior to do open defecation by children

Negative social and family factors are they rarely teach defecation in latrines since childhood. It means that family social factors still bound by habit, custom, and belief of the family, causing the children's behavior to follow the custom in a family. A family is the closest neighborhood where children can imitate whatever the family does.Not only does negative social and family factor encourage someone to do open defecation but also the society with positive value still do conduct open defecation because of parental attention that can be caused by large family and defecation habit.

The majority of respondents had good religiosity on the behavior of open defection.There is a relationship based on the test Spearman Rho between religiosity and parental behavior of open defecation children. The level of relationship's category was moderate. Religion is a symbol which makes people very realistic. Religion gives strong motivation to put the truth above others, even its life. Religion causes the person to have humility and opening (Leininger, 2002).

Religiosity is a core of human life. High religiosity is described by their belief in the existence of God as manifested in the process of studying knowledge and behavior by its religion. The behavior of obeying what is ordered and disobeying what is forbidden by the religion will make human closer to God, the sense that prayers are being said is always granted, a sense of calm, and so on. So that, the daily activity of individual truly reflects the teaching of religion (Purnamasari 2014).

In this study, all respondents had a good rate of religiosity, but some of them were a negative behavior of open defecation by 51 respondents $(53.7 \%)$. People who did proper defecation is caused by the religiosity because it led to the observance of obligations as religious people and always maintain personal hygiene but still had to defecate in private place. It is affected by a habit of family and community in the understanding of open defecation inappropriate.

Mostly, respondents owned good technology, but among them, there still had the negative value of behavior open defecation. It showed that there was correlation bySpearman Rho between technology and parental behavior of open defecation to children with a moderate level category.

According to the theory of Transcultural Nursing by Leininger (2002), technology is a factor that influences individual behavior based on culture. Health technology is the infrastructure that allows individual to choose or get a bid to solve health care problem. Utilization of health technology is influenced by the attitude of health worker, the needs, and public interest (Giger 2013). Technology refers to all forms of technology used for creating, saving, modifying, and using information.

There were respondents who had good technology but did the behavior of open defecation, it means that the influence of technology on the behavior of open defecation could also be less influence if there were other factors explained on qualitative research (Mukherjee 2011), people living near the river are likely to defecate in the open area. Another study mentions that the distance between home and the river affects 132 times not to use latrine (Salah, 2002). Another factor that could reduce the technology's role was culture. The culture of open defecation in the open area makes people think that it is easier and simple, this defecation habit is community identity and inheritance - generation of the ancestor so that it becomes a habit (Murwati 2012). 
The technology referred to in this research is health education about open defecation or a healthy family latrine and latrine ownership that meets the health requirements of the respondents. Respondents had had latrine but there were still many people who have not qualified healthcare equipped with septic tanks or have toilets and the lack of information about the benefits to defecate in latrines for health so that respondents still went to the river.

\section{CONCLUSION}

Parental education background factor, economic background, cultural value and lifestyle, social value and family, religiosity and technology is related to open defecation behavior in school-aged children. Further research is expected to provide the intervention of the factors that influence open defecation behavior to children, especially on factors such as cultural value and lifestyle of parents, social and family value.

\section{REFERENCES}

Dinas Kesehatan Kabupaten Lombok Barat, 2012. Profil Kesehatan Kabupaten Lombok Barat Tahun 2012, Lombok Barat: Dinas Kesehatan Kabupaten Lombok Barat.

Friedman, 2010. Buku ajar keperawatan keluarga: Riset, Teori dan Praktek, Jakarta: EGC.

Giger, J. dan D., 2013. Transcultural Nursing: Assesmentand Intervention, Canada: Mosby.

Imelda, S., 2002. Faktor Sosial Budaya yang Mempengaruhi Perilaku Kesehatan Masyarakat Menuju Paradigma Sehat di Kota Padang. Universitas Indonesia.

Kharismawati, E., 2014. Analisis Faktor Pemberian Asi Eksklusif Pada Bayi Berdasarkan Teori Perilaku Who Di Wilayah Puskesmas Mulyorejo Surabaya. Universitas Airlangga.

Koentjaraningrat, 2004. Manusia dan Kebudayaan di Indonesia, Jakarta: Djambatan.

Latifah, F., 2012. Hubungan Karakteristik Anak Usia Sekolah Dengan Kejadian Bullying Di Sekolah Dasar X Di Bogor. Universitas Indonesia.

Leininger, M., 2002. Culture Care Theory: A
Major Contribution to Advance Transcultural Nursing Knowledge and Practices. Journal of Transcultural Nursing, 13(3), pp.189-192. Available at: http://journals.sagepub.com/doi/10.1177/ 10459602013003005 [Accessed May 27, 2017].

Mukherjee, N., 2011. Factors Associated with Achieving and Sustaining Open Defecation Free Communities Learning from East Java, Water and Sanitation Program., Washington, DC.

Murwati, M., 2012. Faktor Host Dan Lingkungan Yang Mempengaruhi Perilaku Buang Air Besar Sembarangan/(Open Defecation). Undip.

Purnamasari, S., 2014. Religiusitas Pada Remaja Ditinjau Dari Minat terhadap Musik Islami, Pop dan music Metal. Universitas Muhammadiyah Surakarta.

Qudsiyah WA; Pujiati, RS; Ningrum, P., 2015. Faktor-Faktor Yang Berhubungan Dengan Tingginya Angka Open Defecation Di Kabupaten Jember. universitas jember. Available at: http://repository.unej.ac.id/bitstream/hand le/123456789/61805/Wahyu Afiatul Qudsyah92110101101_1.pdf?sequence $=1$ [Accessed December 16, 2016].

Sabrina, R., Antariksa, A., \& Prayitno, G., 2010. Sabrina, R., Antariksa, A., \& Prayitno, G. (2010). Pelestarian Pola Permukiman Tradisional Suku Sasak Dusun Limbungan Kabupaten Lombok Timur.

Syaltut, M., 2016. Analisis Faktor Pemberian Mp-Asi Dini Pada Bayi Usia 0-6 Bulan Berdasarkan Teori Transcultural Nursing Di Puskesmas Proppo Pamekasan. Universitas Airlangga.

Widowati, N.., 2015. Hubungan Karakteristik Pemilik Rumah Dengan Perilaku Buang Air Besar Sembarangan Di Wilayah Kerja Puskesmas Sambungmacan II Kabupaten Sragen. Universitas Muhammadiyah, Surakarta. 